\title{
Analisis Berpikir Kritis Siswa SMAN 4 Padang pada Materi Pencemaran Lingkungan
}

\author{
Rosyidah Syahrul $^{1)}$, Ramadhan Sumarmin ${ }^{2)}$, Helendra' ${ }^{1)}$, Relsas Yogica ${ }^{1)}$ \\ ${ }^{1)}$ Prodi Pendidikan Biologi Jurusan Biologi FMIPA Universitas Negeri Padang \\ ${ }^{2)}$ Prodi Biologi Jurusan Biologi Universitas Negeri Padang \\ ramadhan_sum@fmipa.unp.ac.id
}

\begin{abstract}
The individual's capacity to be effective in life is determined by his reasoning abilities, especially with the ultimate goal of overcoming life's problems. Basic reasoning is a clear and coordinated cycle of reasoning used in critical, dynamic thinking, investigating and leading logical examinations. This research aims to determine the critical thinking abilities of students at SMAN 4 Padang on Environmental Pollution Material. This type of research is descriptive, the sample is determined by proportional random sampling. The sample size was 125 students from $50 \%$ of each class member who were taken randomly. Students' critical thinking tests are analyzed per indicator consisting of: Analysis, Evaluation, Deductive and Inductive. Based on the results of the critical thinking analysis of students at SMAN 4 Padang, the average percentage was $71.99 \%$ in the high category. Almost any part of the upper level character can be balanced in the student, so that one can make tentative decisions.
\end{abstract}

Keywords : Critical Thinking, Student SMAN 4 Padang

This is an open access article distributed under the Creative Commons 4.0 Attribution License, which permits unrestricted use, distribution, and reproduction in any medium, provided the original work is properly cited. $\odot 2018$ by author and Universitas Negeri Padang.

\section{PENDAHULUAN}

Keterampilan berrpikir merupakan salah satu kemampuan dasar yang harus diciptakan melalui sistem pendidikan (Depdiknas, 2003). Kapasitas individu untuk menjadi efektif dalam hidup ditentukan oleh kemampuan penalarannya, terutama dengan tujuan akhir untuk mengatasi masalah hidup yang dihadapinya. Salah satu tujuan dari mendirikan Republik ini adalah untuk mencerdaskan kehidupan bangsa yang dinyatakan dalam Pembukaan UUD 1945.

Sistem pendidikan nasional yang disusun oleh pemerintah dalam UU No. 20 Tahun 2003 pada Bab 2 Pasal 3 yang menjelaskan tentang Fungsi dan tujuan dari Pendidikan Nasional. Menurut Barnawi \& Arifin (2016, hal. 45-46) keberhasilan fungsi dan tujuan Pendidikan Nasional ditentukan oleh dua hal penting yang harus diwujudkan lembaga pendidikan yaitu : 1 . Membangun kapasitas siswa, dan; 2. Membentuk kepribadian siswa. Peningkatan kapasitas siswa diidentikan dengan kualitas sekolah, sedangkan membentuk watak atau karakter siswa diidentikan dengan mewujudkan lulusan yang berakhlak baik.

Menurut Anies Baswedan Gubernur DKI Jakarta dalam Reuni Akbar Pesantren Islam ArIrsyad (Rudy, 2018) menyatakan bahwa dunia pendidikan mestinya mendidik anak-anak untuk bisa menang di zamannya. Artinya memberikan bekal kepada siswa bukanlah bekal yang berasal dari pengalaman masing-masing guru di masa lalu, tetapi justru bekal yang dibutuhkan mereka untuk di masa depan. Sehingga diharapkan, pendidikan yang dilaksanakan sekarang dimaksudkan untuk mempersiapkan siswa agar dapat terjun ke dunia kerja dan berkiprah dalam masyarakat dimasa yang akan datang secara konstributif dan produktif.

Dalam dunia pendidikan dibutuhkan pembekalan bagi siswa untuk masa depannya yaitu: selain kebutuhan utama bagi mereka adalah iman, takwa, akhlak yang harus dipegang. Juga 4 dasar kemampuan yang harus dimiliki siswa diantaranya: 1. Kemampuan berpikir kritis; 2. Kemampuan berkreasi; 3. Kemampuan untuk berkomunikatif, dan; 4. Kemampuan bekerjasama. Yang disingkat 4K oleh Anies Baswedan (Rudy, 2018).

Menurut Ennis (2011), kapasistas berpikir kritis adalah kemampuan untuk berpikir secara objektif dan reflektif bahwa konsentrasi sesuai dengan kenyataan dan mengambil apa yang harus diselesaikan. Sementara itu, diindikasikan dalam rujukan Kamus Besar Bahasa Indonesia (KBBI) terdapat 3 sifat yang diartikan dari kata kri-tis, yaitu: suatu sifat yang tidak mudah percaya, selalu berupaya menemukan kesalahan/kekeliruan, dan cermat dalam penganalisisan. Dapat disimpulkan suatu 
proses berpikir yang terarah dan jelas dengan tidak mudah percaya, berusaha menemukan permasalahan yang terjadi, menganalisis, pengambilan keputusan serta melakukan penelitian ilmiah merupakan keterampilan dalam berpikir kritis.

Materi yang dikenalkan dan pertemuan siswa yang disusun oleh pendidik akan membuat kesan siswa pada bidang keilmuan. Padahal sampai saat ini, biologi secara umum diperkenalkan dalam bentuk istilah latin, klasifikasi, anatomi, morfologi yang perlu diingat siswa. Hal inilah yang membentuk kesan siswa terhadap biologi, bahwa biologi adalah ilmu yang menggaris bawahi sebagai ilmu hafalan. Terlepas dari kenyataan bahwa, biologi sebenarnya adalah sains yang membutuhkan pemahaman, penerapan, penyelidikan, sintesis dan penilaian atau pemikiran yang lebih tinggi atau mempertimbangkan pembelajaran biologi untuk memanfaatkan pertanyaan apa, mengapa dan bagaimana (Lufri dkk, 2007: 18).

Bloom menyatakan bahwa kemampuan spekulasi dasar pada manusia dapat diisolasi menjadi enam kelas, lebih spesifiknya: 1 . Pengetahuan 2. Pemahaman 3. Penerapan 4. Analisis 5. Sintesis, dan 6. Evaluasi. Tiga kelas awal adalah kemampuan penalaran yang solid, sedangkan analisis, sintesis dan penilaian lebih bersifat konseptual dan dikenal sebagai kemampuan penalaran dasar (Djamas, 2012: 23). Menurut Bono dalam buku Sudarma (2013: 95), berpikir kritis diibaratkan dengan topi gelap. Topi gelap adalah topi yang luar biasa dan kemungkinan besar paling berharga dari semuanya. Bagaimanapun, topi gelap menghalangi seseorang melakukan hal-hal yang tidak benar, terlarang dan berbahaya. Sifat dari topi gelap itu kritis, dan kecenderungannya untuk menilai atau mengevaluasi.

Berdasarkan permasalahan di atas, bahwa perlunya bagi siswa memiliki berpikir kritis untuk dapat mewujudkan salah satu tujuan dari Republik Indonesia, yaitu menjadikan kehidupan bangsa lebih cerdas. Sehingga inisiatif peneliti untuk melakukan penelitian tentang Analisis Berpikir Kritis Siswa di SMAN 4 Padang pada Materi Pencemaran Lingkungan. Sehingga data yang diperoleh dari hasil penelitian, dapat digunakan bagi guru sebagai tolak ukur untuk melakukan pembelajaran yang lebih efisien dalam mengasah kemampuan berpikir kritis yang dimiliki siswa.
Pada Kompetensi Dasar Pencemaran Lingkungan membahas tantang menganalisis sebab dan akibat dari permasalahan pencemaran lingkungan, materi tersebut erat kaitannya dengan kehidupan sehari-hari. Menurut Achmad (2007) dengan belajar mengidentifikasi masalah atau sumber masalah utama yang berdampak pada munculnya masalah lain, yang terjadi berhubungan dengan kehidupan sehari-hari atau yang berada di sekitar siswa akan membantu memudahkan siswa mengemukakan ide pemecahan masalah yang membangun serta melatih kemampuan berpikir kritis siswa.

\section{METODE PENELITIAN}

Penelitian ini merupakan penelitian deskriptif, bertujuan untuk mengetahui tingkat kemampuan berpikir kritis siswa SMAN 4 Padang. Teknik pengambilan sampel yang digunakan dalam penelitian ini adalah proposive random sampling. Setiap kelas memiliki peluang yang sama untuk dijadikan sampel penelitian. Prosedur pengambilan sampel sebanyak 125 siswa dilakukan dengan tahapan berikut : (1) Penetapan sampel sebanyak 50\% tiap kelas XI MIPA 1 - XI MIPA 7; (2) Masing-masing kelas diambil sebanyak 17 - 18 siswa secara acak, dan; (3) Pengambilan sampel dilakukan sebanyak 125 siswa yang terdiri dari XI MIPA 1 - XI MIPA 7.

Instrumen yang digunakan berupa tes bentuk essay sebanyak 4 soal untuk menguji 4 indikator berpikir kritis yang diadopsi dari tesis Dodi Hartono (2017), dan data tentang faktor yang mempengaruhi kemampuan berpikir kritis siswa didapatkan dengan cara wawancara salah satu guru dan melakukan pengamatan selama periode PLK di SMAN 4 Padang.

Penilaian hasil tes dilakukan menggunakan rentang $1-4$ kemudian diolah dalam bentuk nilai dengan rentang $0-100$. Rumus pengolahan skor menjadi nilai adalah sebagai berikut.

$$
\text { Nilai }=\frac{\text { skor yang diperoleh }}{\text { total skor }} \times 100 \%
$$

Nilai yang diperoleh kemudian diinterprestasikan untuk mengetahui tingkat kemampuan berpikir kritis siswa mengacu pada interval interpretasi nilai yang digunakan Karim \& Normaya dalam Dodi (2017) yang disajikan seperti tabel 1.

Tabel 1.Kriteria Kemampuan Berpikir Kritis 


\begin{tabular}{|c|c|c|}
\hline Interpretasi (\%) & Kategori & $\begin{array}{c}\text { Ket. } \\
\text { Warna }\end{array}$ \\
\hline $81,25<\mathrm{x} \leq 100$ & Sangat Tinggi & \\
$71,5<\mathrm{x} \leq 81,25$ & Tinggi & \\
$62,5<\mathrm{x} \leq 71,5$ & Sedang & \\
$43,75<\mathrm{x} \leq 62,5$ & Rendah & \\
$0<\mathrm{x} \leq 43,75$ & Sangat Rendah & \\
\hline
\end{tabular}

A. Hasil

Data hasil penelitian yang diperoleh, adalah data primer yang dilakukan secara daring (online) menggunakan Google from. Pada Tabel 2 dapat diketahui bahwa hasil dari tes berpikir kritis siswa SMAN 4 Padang cukup bervariasi dan didominasi oleh kategori tinggi.

\section{HASIL DAN PEMBAHASAN}

Tabel 2. Persentase Nilai Kemampuan Berpikir Kritis Siswa SMAN 4 Padang

\begin{tabular}{|c|c|c|c|c|c|c|c|c|c|c|}
\hline & \multicolumn{2}{|c|}{ Analisis } & \multicolumn{2}{|c|}{ Evaluasi } & \multicolumn{2}{|c|}{ Deduktif } & \multicolumn{2}{|c|}{ Induktif } & \multirow{2}{*}{ Jumlah } & \multirow{2}{*}{ Keterangan } \\
\hline & $\%$ & Kategori & $\%$ & Kategori & $\%$ & Kategori & $\%$ & Kategori & & \\
\hline XI MIPA 1 & 73,61 & Tinggi & 65,28 & Sedang & 73,61 & Tinggi & 76,39 & Tinggi & 72,22 & Tinggi \\
\hline XI MIPA 2 & 75 & Tinggi & 88,89 & $\begin{array}{l}\text { Sangat } \\
\text { Tinggi }\end{array}$ & 76,39 & Tinggi & 77,78 & Tinggi & 79,52 & Tinggi \\
\hline XI MIPA 3 & 79,17 & Tinggi & 63,89 & Sedang & 75 & Tinggi & 61,11 & Rendah & 69,79 & Sedang \\
\hline XI MIPA 4 & 87,5 & $\begin{array}{l}\text { Sangat } \\
\text { Tinggi }\end{array}$ & 81,94 & $\begin{array}{l}\text { Sangat } \\
\text { Tinggi }\end{array}$ & 69,44 & Sedang & 75 & Tinggi & 78,47 & Tinggi \\
\hline XI MIPA 5 & 50 & Rendah & 58,33 & Rendah & 54,17 & Rendah & 61,11 & Rendah & $\mathbf{5 5 , 9 0}$ & Rendah \\
\hline XI MIPA 6 & 69,44 & Sedang & 65,28 & Sedang & 76,39 & Tinggi & 70,83 & Sedang & 70,49 & Sedang \\
\hline XI MIPA 7 & 73,53 & Tinggi & 77,94 & Tinggi & 79,41 & Tinggi & 79,41 & Tinggi & 77,57 & Tinggi \\
\hline Total & 72,61 & Tinggi & 71,65 & Tinggi & 72,06 & Tinggi & 71,66 & Tinggi & 71,99 & Tinggi \\
\hline
\end{tabular}

Hasil analisis berpikir kritis secara keseluruhan siswa di SMAN 4 Padang memperoleh rata-rata 71,99 dengan kategori tinggi. Berdasarkan pengukuran dari subskala berpikir kritis siswa SMAN 4 Padang memiliki nilai ratarata persentase tiap indikator, yaitu: pada indikator analisis diperoleh $72,61 \%$, indikator evaluasi $71,65 \%$, indikator deduktif $72,06 \%$, dan indikator induktif $71,66 \%$. Semua indikator berpikir kritis diperoleh siswa SMAN 4 Padang merupakan kategori tinggi.

Berdasarkan analisis hasil data berpikir kritis yang diperoleh siswa, memiliki tingkat kategori yang berbeda dari masing-masing kelas XI Mipa di SMAN 4 Padang. Diantaranya dari hasil data yang diperoleh pada kategori tinggi, yaitu: kelas XI Mipa 2 dengan nilai persentase 79,52\%; kelas XI Mipa 4 dengan nilai persentase 78,47\%; kelas XI Mipa 7 dengan nilai persentase $77,57 \%$ dan kelas XI Mipa 1 dengan nilai persentase $72,22 \%$. Beberapa kelas lainnya, pada kategori sedang yaitu: kelas XI Mipa 6 dengan nilai persentase $70,49 \%$ dan kelas XI Mipa 3 dengan nilai persentase 69,79\%. Dan kelas dengan kategori rendah yaitu kelas XI Mipa 5 dengan nilai persentase $55,90 \%$. Hasil data menunjukan kemampuan berpikir kritis siswa di SMAN 4 Padang di dominasi oleh kelas-kelas yang memiliki kemampuan berpikir kritis yang cukup baik.

\section{B. Pembahasan}

Dalam usaha mengetahui tingkat berpikir kritis siswa di SMAN 4 Padang pada materi pencemaran lingkungan. Keterampilan berpikir tingkat tinggi yang harus dimiliki dan dikembangkan, salah satunya adalah kemampuan dalam berpikir kritis. Memberikan tujuan yang jelas saat berpikir, bekerja dan menemukan keterkaitan sesuatu dengan yang lain, merupakan kelebihan seseorang dalam berpikir kritis. Ennis (2011) menyatakan bahwa kemampuan untuk berpikir secara objektif dan reflektif bahwa konsentrasi sesuai dengan kenyataan dan mengambil apa yang harus merupakan cara berpikir seseorang dalam berpikir kritis. Mengetahui dan mempersiapkan siswa dengan bekal keterampilan berpikir kritis, diharapkan siswa dapat terjun kedunia kerja dan berkiprah dalam masyarakat dimasa yang akan datang secara kontributif dan produktif.

Instrumen pengambilan data penelitian berpikir kritis ini dilakukan melalui tes esay/ soal 
uraian yang diadopsi dari tesis Dodi Hartono (2017). Tes penilaian yang dikembangkan Dodi (2017) mengacu pada indikator berpikir kritis yang mengembangkan soal pada tingkat kemampuan analisis, evaluasi, berpikir deduktif dan berpikir induktif. Integrasi atau pembaruan kemampuan pada: pengamatan (observasi), analisis, penalaran, penilaian, pengambilan keputusan, dan persuasi, merupakan pengembangan kemampuan dari berpikir kritis. Kemampuan tersebut dilakukan saat muncul atau diberikannya suatu permasalahan, seseorang yang memiliki kemampuan berpikir kritis akan terbiasa melakukan pengematan (observasi) dari permasalahan tersebut, hingga pengambilan keputusan dan persuasi.

Penilaian dalam pengukuran berpikir kritis yang dilakukan oleh Dodi mengacu pada pengembangan yang dilakukan oleh Philips et, al (2004) dari 5 (lima) subscales khusus yaitu: 1. Analysis; 2. Evaluation; 3. Inference; 4. Deductive reasoning, and; 5. Inductive reasoning. Pada penelitian ini dilakukan beberapa indikator sebagai tolak ukur penilaian pada siswa dalam kemampuan berpikir kritis, diantaranya: analisis, evaluasi, deduktif dan induktif.

\section{Analisis}

Hasil data tingkat kesiapan siswa pada indikator analisis ini adalah 72,61\% termasuk dalam kategori tinggi. Hasil data menunjukan siswa di SMAN 4 Padang sudah mampu untuk menganalisis suatu masalah yang muncul atau yang diberikan. Menunjukan bahwa siswa sudah mampu untuk menghubungkan antara konsep dan informasi yang disajikan serta memberikan solusi dari permasalahan disertakan alasan solusi yang diberikan.

Berdasarkan hasil data kemampuan siswa mengenai analisis, menunjukan siswa sudah mulai terbiasa dengan suatu data yang bervariasi, pengamatan dan pertimbangan. Djamas (2012: 38) menyatakan kemampuan analisis membantu memahami dan mengungkapkan pentingnya atau signifikansi dari bermacam-macam informasi, pertemuan, dan perenungan. Kapasitas ini mencakup kemampuan untuk mengatur, memutuskan makna, dan menjelaskan makna. Untuk mendapatkan beberapa jawaban tentang pemikiran, mengenali kecurigaan, alasan dan untuk mengumpulkan data terperinci dari bagan, garis besar, paragraph dan lain-lain.

\section{Evaluasi}

Nilai rata-rata kesiapan siswa berpikir kritis pada indikator evaluasi adalah $71,65 \%$ dengan kategori tinggi. Siswa yang memiliki kemampuan ini adalah individu yang mampu membuat sebuah ikhtiar atau menyimpulkan dalam mengatasi sebuah permasalahan yang diberikan, yaitu mampu menilai dampak positif dan negatif dari aktivitas penambangan emas dan berusaha memecahkan permasalahan tersebut dengan menyertakan alasan yang benar dan tepat. Untuk mengevaluasi secara fundamental tergantung pada pilihan yang diterima, melalui apa yang mendasari anggapan ini dan sudut pandang kehidupan yang menghubungkan kecurigaan ini, adalah aura dan kapasitas untuk berpikir kritis (Tilar, 2011).

Keterampilan menilai menghendaki siswa agar memberikan penilaian tentang nilai yang diukur dengan menggunakan standar tertentu. Djamas (2012: 32) menyatakan keterampilan evaluasi menuntut pemikiran yang matang dalam menentukan nilai sesuatu dengan berbagai kriteria yang ada.

3. Deduktif

Tingkat kesiapan siswa pada indikator deduktif ini, adalah $72,06 \%$ dengan kategori tinggi. Pada indikator ini, siswa yang mampu menjelaskan masalah dan menghubungkan dengan konsep serta menyampaikan solusi dan alasan yang tepat sesuai permasalahan yang diberikan soal.

Kemampuan siswa pada subskala pemikiran deduktif ini adalah mengukur kemampuan yang dimulai dari hal bersifat umum atau premis yang dianggap benar, sampai pada kesimpulan yang bersifat khusus. Sternberg (2009: 507) menyatakan bahwa, strategi deduktif (atau pemikiran deduktif) adalah siklus berpikir dari setidaknya satu pernyataan umum (premis) untuk sampai pada hasil akhir tertentu yang jelas. Untuk menghasilkan kesimpulan dibutuhkan sebuah proses berpikir yang memperdayakan pengetahuannya.

\section{Induktif}

Tingkat kesiapan siswa pada indikator induktif ini, adalah 72,06\% dengan kategori tinggi. Pada indikator ini, siswa yang mampu menganalisis masalah dan menghubungkan dengan konsep serta menyampaikan solusi dan alasan yang tepat sesuai yang diinginkan soal. Kemampuan siswa pada subskala penalaran induktif ini, adalah kapasitas untuk melibatkan pemikiran premis dan penggunaan informasi dan pengalaman terkait, untuk sampai pada resolusi umum. 
Berdasarkan hasil penelitian analisis tingkat kemampuan berfikir kritis siswa di SMAN 4 Padang diperoleh hasil rata-rata persentase adalah $71,99 \%$ dengan kategori tinggi. Tercapainya kapasitas penalaran dasar ini ditunjang dengan adanya kerangka sekolah yang menunjang tinggi kerangka pembelajaran tersebut, salah satu model pembelajaran yang ditetapkan oleh pengajar adalah dengan memanfaatkan model pembelajaran Problem Solving. Pemikiran belajar untuk pemahaman dan berpikir kritis umumnya ditentukan oleh iklim belajar di mana siswa berinteraksi secara akademis dalam membangun wawasannya. Pembelajaran berbasis masalah sangat penting, karena dalam beradaptasi sebagian besar siswa akan cepat mengabaikan jika hasilnya dijelaskan secara lisan, mereka mengingat apakah model yang diberikan dan memahami jika diizinkan kesempatan untuk mencoba menangani masalah (Djamas, 2012: 50).

Model pembelajaran berfikir kritis yang menekankan pada pencarian dan penemuan respon terhadap suatu permasalahan samar secara otonom melalui pengujian logika menunjukkan bahwa siklus pembelajaran bersifat dasar dan ilmiah bagi siswa. Didukung oleh hasil eksplorasi yang dilakukan oleh Hasanah dkk, (2018) menunjukan bahwa model pembelajaran berbasis masalah (Problem Based Learning) secara positif mempengaruhi kemampuan penalaran dasar siswa. Model PBL juga dapat memperluas inspirasi, pengalaman dan informasi siswa serta kapasitas untuk menangani maslah dibandingkan dengan menggunakan model Discovery Learning (Chodijah, dkk., 2019).

Kemampuan penalaran dasar dapat menyesuaikan siswa dengan menangani kesulitan yang terjadi dan berusaha untuk menangani masalah tersebut, siswa tidak hanya bisa memberi solusi dalam menyelesaikan masalah tersebut melainkan juga memberi alasan yang tepat kenapa solusi pemecahan masalah tersebut diusulkan. Berdasarkan perolehan hasil rata-rata dan analisis berpikir kritis siswa kelas XI Mipa di SMAN 4 Padang dalam tingkat kategori tinggi, dan perlu adanya peningkatan terutama pada kelas yang berada pada kategori rendah dan sedang. Berpikir kritis haruslah secara beruntun dan pelan-pelan dilatih dan dibentuk pada siswa. Sesuai dengan pernyataan yang disampaikan Djamas (2012: 17) bahwa, berpikir kritis adalah kapasitas dan kecendrungan yang sebenarnya harus disiapkan lebih awal dari jadwal dan sesering yang diharapkan.

Dari hasil data penilaian berpikir kritis masih adanya siswa dari beberapa kelas yang berada pada kategori sedang dan rendah, dikarenakan siswa kurang siap untuk berpikir secara fudamental, karena dalam belajar, siswa sebenarnya fokus pada pengukuran memori dan memahami (Agnafia, 2019: 51). Terbukti dari jawaban yang diberikan oleh beberapa siswa yang masih memiliki jawaban yang kurang benar dan kurang tepat pada konsep materi pencemaran lingkungan. Berdasarkan pengamatan peneliti saat melakukan tugas PLK di SMAN 4 Padang sebagai guru biologi, siswa sering mengeluh ketika dilakukan tes tertulis. Berdasarkan pernyataan siswa, biasanya pelaksanaan ulangan harian dilakukan dengan cara lisan pada pembelajaran biologi. Menurut Fatmawati dkk, (2014) menyatakan bahwa ada beberapa hal yang dapat mempengaruhi kemampuan penilaan dasar siswa antara lain: a) siswa tidak terbiasa dengan pertanyaan cerita sehingga siswa kurang siap untuk memahami pertanyaan; b) siswa kurang siap untuk mengubah cerita menjadi model numerik sehingga siswa mengalami masalah dalam menyelesaikan permasalahan, dan; c) siswa pada umumnya akan menangani masalah menggunakan hanya satu rute tanpa fokus pada cara lain, jadi siswa secara teratur tidak memeriksa efek samping dari pekerjaan mereka setelah selesai.

Berdasarkan hasil data berpikir kritis siswa SMAN 4 Padang memiliki nilai bervariasi dari beberapa kelas yang melakukan tes berpikir kritis, yaitu dari nilai tertinggi yang memperoleh $79,52 \%$ dan nilai terrendah ialah 55,90\%. Hal tersebut dibutuhkan suatu upaya agar terus dijaga dan diusahakan untuk meningkatkan kemampuan berpikir kritis siswa di SMAN 4 Padang. Untuk membantu memfokuskan dan mengoptimalkan kemampuan berpikir kritis siswa selama proses pembelajaran, maka implementasi strategi Problem Solving dibantu menggunakan lembar panduan bagi peserta didik seperti menggunakan LKPD STEM dapat membantu mengasah berpikir kritis siswa.

Pendidikan STEM sejalan dengan keterampilan abad 21, yakni: crativity, critical thinking, collaboration, dan communication (Beers, 2011). Pada pendekatan STEM yang di integrasikan dalam LKPD, yang dikembangkan 
untuk melatih kemampuan berpikir kritis siswa. Menunjukkan bahwa karakteristik keefektifan dan LKPD dapat meningkatkan kemampuan berpikir kritis siswa dinilai dari hasil belajar siswa dan pengamatan siswa selama proses pembelajaran (Ramli, dkk 2020). Melalui LKPD ini membantu siswa menjadi aktif dan mempunyai ketertarikan pada materi pembelajaran yang sedang dibahas.

Melatih kemampuan dasar percaya untuk siswa dan belajar bagaimana menjadi lebih dinamis, juga dapat menggunakan model pembelajaran Inquiry. Penggunaan model pembelajaran Inquiry berpengaruh positif terhadap peningkatan kemampuan berpikir kritis siswa pada materi ekskresi, hal tersebut merupakan hasil eksplorasi yang dilakukan oleh Rahmi (2018). Inquiry sendiri mengandung arti penyelidikan atau permintaan data (Anam, 2017: 7). Meminta panduan model pembelajaran siswa untuk memiliki pilihan agar menemukan sendiri materi yang diperkenalkan dalam pembelajaran, dengan mengajukan pertanyaan dan melakukan investigasi.

Berdasarkan hasil penelitian Wibowo (2016) menyimpulkan bahwa, metode pembelajaran debat aktif dapat menjadi alternatif untuk mendorong siswa yang semula tidak terikat menjadi lebih dinamis dan energik dalam belajar, dengan mengembangkan keteguhan siswa dalam mengkomunikasikan pemikirannya, melindungi pemikirannnya dengan beberapa argumen, dan bereaksi terhadap kesimpulan orang lain. Kritik merupakan salah satu karakter oleh pikir. Salah satu prinsip yang digunakan untuk mengembangkan karakter tersebut, yaitu didukung dengan menunjukan bahwa cara untuk menciptakan nilai karakter adalah sebuah siklus yang panjang, dimulai dari awal siswa memasuki jenjang pendidikan hingga selesai (Djamas, 2012: 93).

Melalui strategi pembelajaran yang digunakan akan dapat ditumbuh kembangkan berbagai potensi siswa, seperti potensi intelektual, sosial, mental dan emosi. Menurut Djamas $(2012 ; 79)$ prosedur yang berkelanjutan dan cermat merupakan bagian dari berpikir kritis. Hingga siswa dapat menjadi seseorang pemikir kritis, maka perlu dilakukan latihan secara terus menerus baik melalui penggunaan strategi pembelajaran, menggunakan LKPD pembelajaran, metode pembelajaran dan ulangan harian yang didalam kegiatannya, dapat mengembangkan secara optimal kemampuan berpikir kritis.

Mengikutsertakan siswa dalam memenuhi kebetuhan mereka sendiri untuk merencanakan kehidupan masa depan dengan tidak memberikan mereka sesutu yang telah diatur (Tilar, dkk. 2011: 17). Sejalan dengan penelitian yang diarahkan oleh Yogi, dkk. (2019) menyimpulkan bahwa penting bagi siswa untuk mendominasi kemajuan zaman seperti sain dan inovasi dengan basis data Modern Insurgency 4.0. yang bersaing di seluruh dunia. Ini adalah tugas pendidik untuk mengkoordinasikan pembelajaran menuju ketersediaan siswa untuk menghadapi periode Modern Insurgency 4.0. ini dan tugas sekolah untuk peka terhadap perubahan kebutuhan sekolah dan lulusan sekolah melalui saat melakukan ujian dan estimasi yang berbeda.

\section{KESIMPULAN}

Hasil penelitian yang telah dilakukan, menunjukkan bahwa berpikir kritis siswa SMAN 4 Padang dianalisis per indikatornya memperoleh penilain yaitu: pada indikator analisis $72,61 \%$, indikator evaluasi $71,65 \%$, indikator deduktif $72,06 \%$, dan indikator induktif $71,66 \%$ dengan rata-rata kategori tinggi tiap indikatornya.

Berdasarkan hasil penelitian, diketahui bahwa berpikir kritis siswa di SMAN 4 Padang pada materi pencemaran lingkungan diperoleh rata-rata persentase $71,99 \%$ dengan kategori tinggi. Hampir semua bagian karakteristik berpikir tingkat tinggi terimplementasikan pada siswa, di mana hingga seseorang dapat mengambil sebuah keputusan tentatif.

\section{DAFTAR PUSTAKA}

Achmad, A. 2007. Memahami Berpikir Kritis. Bandung: Artikel Pendidikan.

Anam, K. 2017. Pembelajaran Berbasis Inkuiri, Metode dan Aplikasi. Yogyakarta: Pustaka Pelajar.

Agnafia, D. N. 2019. Analisis Kemampuan Berpikir Kritis Siswa Dalam Pembelajaran Biologi. Florea, 45-53.

Arafin, B. \&. 2016. Strategi \& Kebijakan Pembelajaran Pendidikan Karakteristik. Jogjakarta: Ar-Ruzz Media.

Beers. 2011. 21st Century Skills: Prepering Students For Their Future. Diambil dari: 
https://www.yinguaacademy.org/wpconte nt/uploads/2014/10/21stcenturyskills.pdf.

Chodijah, R. S., Rais, M., \& Hadi, N. 2019. Perbedaan Problem Based Learning dan Discovery Learning Terhadap Pemahaman Sistem Reproduksi Tumbuhan dan Hewan. Jurnal Pendidikan dan Biologi, 55-58.

Djamas, D. 2012. Pengembangan Berpikir Kritis Berbasis Problem Based Learning. Padang: Universitas Negeri Padang.

Ennis, R. H. 2011. the Nature of Critical Thinking: An Outline of Critical Thinking Dispusitions and Abilties. Chicago: Univ of Illiniois.

Fatmawati, H., Mardiyana, \& Triyanto. 2014. Analisis Berpikir Kritis Siswa dalam Pemecahan Masalah Matematika Berdaskan Pola pada Pokok Bahasan Persamaan Kuadrat. Jurnal Elektronik Pembelajaran Matematika: 899-910.

Hartono, Dodi. 2017. Pengeruh Model Pembelajaran Problem Based Learning Terhadap Kemampuan Berpikir Kritis dan Kompetensi Belajar Biologi Siswa Kelas X MIA SMA Negeri 3 Sungai Penuh. Padang: Program Pascaserjana UNP.

Hasanah, M. D., Alberida, H., \& Rahmi, Y. L. (2018). The Effect of Problem Based Learning Model on Critical Thinking Ability of Students on Additives and Addictive Substances Class VIII SMPN 12 Padang. Bioeducation Journal, 2(2), 124-132.

Lufri. 2007. Kiat Memahami Metodologi dan Melakukan Penelitian. Padang: UNP Press.

Lufri, Yunusr, Y., \& Sudirman. 2007. STRATEGI PEMBELAJARAN BIOLOGI (Vol. 50). Padang: FMIPA UNP.

Philips, C. R., Chesnut, R. J., \& Rospond, R. 2004. The California Critical Thinking Instruments for Benchmarking, Program Assessment, and Directing Curricular Change. American Jurnal of Pharmaceutical Education, 68(4) , 101.

Rahmi, Y. L., Alberida, H., \& Astuti, M. Y. (2019, October). Enhancing students' critical thinking skills through inquiry- based learning model. In Journal of Physics: Conference Series (Vol. 1317, No. 1, p. 012193). IOP Publishing.

Ramli, Yohandri, Sari, Y. S., \& Selisne, M. 2020. Pengembangan Lembar Kerja Peserta Didik Fisika Berbasis Pendekatan Science, Teknology, Engineering, and Mathematics untuk Meningkatkan. JEP (Jurnal Eksakta Pendidikan), 10-17.

Rudy, M. (2018, January Minggu). Gubernur Anies Ingatkan Pentingnya Pendidikan Karakter Bagi Anak. Dipetik Maret Sabtu, 2020, dari KIBLAT: https://www.kiblat.net/2018/01/07/gubern ur-anies-ingatkan-pentingnya-pendidikankarakter bagi-anak/

Sternberg, R. J. 2009. Cognitive Psychology. Belmont CA: Wadsworth.

Sudarman, M. 2013. Mengembangkan Keterampilan Berpikir Kritis. Jakarta: Rajawali Pers.

Tilar, H., Jimmy, \& Paat, L. 2011. Padagogik Kritis. Jakarta: Rineka Cipta.

Wibowo, P. W., \& Lestari, E. S. 2016. Penerapan metode Pembelajaran Debat Aktif Dalam Meningkatkan Keaktifan Siswa di Dukung Dengan Media Pembelajaran Berbasis Weblog Kelaskita Pada Mata Pelajaran simulasi Digital di SMK N 1 Ngablak Magelang. Garuda, 19.

Yogica, R., Fuadiyah, S., \& Hasanah, J. 2019. Analisis Kesiapan Peserta Didik SMA Negeri 8 Padang Menghadapi Revolusi Industri 4.0. Jurnal Eksakta Pendidikan (JEP), 176-183.

Yunarti, T. 2009. Pengajaran Berpikir Kritis. Makalah Disajikan Pada Seminar Nasional Pembelajaran Matematika Sekolah, Pada Tanggal 6 Desember 2009 di UNY Yogyakarta.

Yustyan, S., Widodo, N., \& Pantiwati, Y. 2015. Peningkatan Kemampuan Berpikir Kritis dengan Pembelajaran Berbasis Scientific Approach Siswa Kelas X SMA Panjura Malang. Jurnal Pendidikan Biologi Indonesia, 1(2) , 240-254. 
